\title{
Hypertonic saline and hemorrhagic shock: hepatocellular function and integrity after six hours of treatment ${ }^{1}$
}

\author{
Solução salina hipertônica e choque hemorrágico: função hepatocelular e integridade \\ após seis horas de tratamento
}

\author{
Ricardo Antônio Hoppen², Carlos Otávio Corso ${ }^{3}$, Tomáz Jesus Maria Grezzana ${ }^{4}$,Antonio Severino ${ }^{5}$, Felipe Dal-Pizzol', \\ Cristiane Ritter ${ }^{7}$ \\ 1. Study developed at the Postgraduate Course of Surgery, Federal University of Rio Grande do Sul (UFRGS). Porto Alegre, Brazil. \\ 2. MD. Postgraduate Course of Surgery, UFRGS. Porto Alegre, Brazil. \\ 3. MD, PhD, Postgraduate Course of Surgery, Department of Morphological Sciences, UFRGS. Porto Alegre, Brazil. \\ 4. MD, Postgraduate Course of Surgery, UFRGS. Porto Alegre, Brazil. \\ 5. BSc, Department of Morphological Sciences, UFRGS. Porto Alegre, Brazil. \\ 6. MD, PhD, Experimental Physiopathology Laboratory, Universidade do Extremo Sul Catarinense. Criciúma, Santa Catarina, Brazil. \\ 7. Experimental Physiopathology Laboratory, Universidade do Extremo Sul Catarinense. Criciúma, Santa Catarina, Brazil.
}

\begin{abstract}
Purpose: The comparison after 6h of hemorrhagic shock (HS) treatment with NaCl 7.5\% (Hypertonic Saline Solution - SSH) or Ringer Lactate (RL) on liver function and integrity. Methods: Male Wistar rats were submitted to HS (Mean Arterial Pressure $-\mathrm{MAP}=45 \mathrm{mmHg}$ ) during $60 \mathrm{~min}$ and then treated with $\mathrm{NaCl}$ 7.5\% (SSH, 10\% of blood loss, $\mathrm{n}=8$ ) or Ringer Lactate (RL, $400 \%$ of blood loss, n=8). After $6 \mathrm{~h}$ rats were anesthetized, hepatic function was assessed by bile flow measurement and liver integrity evaluated by determination of alanine aminotransferase (ALT) and bilirubin activities. Results: There was no difference in MAP between the groups during the whole experiments. Biliary flow showed a significant recovery after SSH treatment $(\mathrm{p}<0.05)$, and significant decrease of ALT $(\mathrm{p}<0.001)$ and bilirubin levels $(\mathrm{p}<0.001)$ in comparison to RL. Conclusion: Resuscitation of $\mathrm{HS}$ with $\mathrm{NaCl} 7.5 \%$ promoted better recovery of liver function and lesser hepatocellular damage after $6 \mathrm{~h}$ of treatment compared to RL. The improvement is very likely related to increased microvascular perfusion provided by small volume resuscitation.
\end{abstract}

Key words: Ischemia. Reperfusion. Shock, Hemorrhagic. Saline Solution, Hypertonic. Liver. Rats.

\section{RESUMO}

Objetivo: Comparar os efeitos após 6 horas do tratamento do choque hemorrágico $(\mathrm{CH})$ com solução de $\mathrm{NaCl} 7,5 \%$ (Solução Salina Hipertônica - SSH) e Ringer Lactato (RL) sobre a função e integridade hepática em ratos. Métodos: Ratos Wistar ( $\mathrm{n}=16$ ) machos foram submetidos a choque hemorrágico controlado (Pressão Arterial Média - PAM = 45 mmHg) durante 60 minutos e após ressuscitados com SSH (10\% da perda volêmica, n=8) ou RL (4 vezes o volume sangüíneo retirado, n=8). Após 6 horas a função hepática foi determinada pela quantificação do fluxo biliar. A integridade hepática foi avaliada pelas bilirrubinas e pela alanino aminotransferase (ALT). Resultados: Não foi constatada diferença de PAM entre os grupos durante os experimentos. O fluxo biliar apresentou recuperação significativa no grupo SSH em comparação ao grupo RL $(p<0,05)$. O grupo SSH apresentou diminuição significativa nos níveis de ALT ( $<0,001)$ e das bilirrubinas $(\mathrm{p}<0,001)$. Conclusão: Após 6 horas de tratamento do choque hemorrágico a SSH mostrou-se superior ao RL, recuperando a função e a integridade hepatocelular, provavelmente por melhora da perfusão nutricional hepática, e diretamente relacionada ao seu mecanismo de ação.

Descritores: Isquemia. Reperfusão. Choque Hemorrágico. Solução Salina Hipertônica. Fígado Ratos.

\section{Introduction}

Hemorrhagic shock (HS) is one of the major causes of preventable death following trauma. The liver is the second organ most frequently involved in the microvascular and cellular energetic dysfunction after severe or prolonged HS 1;2. The goal of HS resuscitation is the restoration of blood volume and peripheral perfusion. Evidences show that to restore the peripheral perfusion with RL are necessary three or four times the volume of shed blood ${ }^{1 ; 3}$. However, large volumes of RL replacement can be deleterious, resulting in worsening of the tissular oxygenation and perfusion ${ }^{4 ; 5}$. On the other hand, resuscitation with small volume of Hypertonic Saline Solution (HSS - $\mathrm{NaCl} \mathrm{7,5 \% )} \mathrm{is} \mathrm{also} \mathrm{an}$ effective method to restore the cardiac output and organic perfusion ${ }^{3 ; 6 ; 7}$. The therapy is based on the mobilization of endogenous fluids through an osmotic gradient from the intracellular and interstitial compartments to the intravascular ${ }^{8}$. There are strong evidences of hepatic blood supply improvement with HSS treatment ${ }^{9-11}$. At the present moment, the benefits of HSS resuscitation were determined only after short periods of resuscitation, and there are few 
evidences about the maintenance of its effects at late time after treatment of HS ${ }^{12,13}$. Thus, we decided to evaluate the effects of a single dose of HSS in comparison to LR treatment after 6 hours of HS resuscitation on the liver integrity and function in rats.

\section{Methods}

\section{Animals and procedures}

The study was conducted after approval by the ethics committee of the Postgraduate Course of Surgery, and in agreement with the "Guide for the Care and Use of Laboratory Animals” (National Institutes of Health, Bethesda, EUA). Male Wistar rats bred at the Basic Health Sciences Institute of Federal University of Rio Grande do Sul (UFRGS) weighing between 225g and $265 \mathrm{~g}$ were fasted overnight but with free access to water. They were anesthetized with ketamine sulfate $75 \mathrm{mg} / \mathrm{Kg}$ (Ketamin ${ }^{\circledR}$, Cristalia, São Paulo, Brazil) and xylazin $10 \mathrm{mg} / \mathrm{Kg}$ (Virbaxyl®, Virbax of Brazil, São Paulo, Brazil) ip. During the whole experiment anesthetic supplementation was given when necessary. Polypropylene catheters (PE-50, Portex ${ }^{\circledR}$, Kent, England) were used to cannulate the right carotid artery, the right jugular vein, the right femoral artery and the tail artery. The carotid artery was used for bleeding to achieve the desired degree of shock and to obtain the blood samples (T0). To maintain patent lines catheters and to compensate for ion and water losses, catheters were rinsed with $1 \mathrm{ml} /$ $100 \mathrm{~g} \mathrm{BW} / \mathrm{h}$ normal saline. The volume replacement was given by the right femoral vein, and the tail artery was used for continuous recording of MAP. After shock and resuscitation, the carotid artery and jugular vein catheters were occluded and left in the cervical and torso subcutaneous. The tail artery and right femoral vein catheters were withdrawn and the skin closed and anesthetized with 1\% lydocain (Cloridrato de Lidocaína1\%, Geyer Medicamentos $®$, Porto Alegre, Brazil). The rats were allowed to recover in appropriate cages with indirect heating and free water access. After 6 hours, animals were once more anesthetized, catheters rinsed and MAP recorded. A transverse laparotomy was performed, the common bile duct was cannulated, and the bile was collected and measured over the entire length of the experiments and standardized per gram of liver wet weight. At the end of the experiments blood samples (T6) were taken and the animals were sacrificed with lethal doses of sodium thiopental. All blood samples were centrifuged, the plasma frozen and stored at $80^{\circ} \mathrm{C}$ and livers were weighted.

\section{Experimental protocol}

The rats were bled at a rate of $0.5 \mathrm{ml} / \mathrm{min}$ within 10 minutes to induce shock (MAP, $45 \mathrm{mmHg}$ ) and this level was kept for $60 \mathrm{~min}$. Further bleeding or reinfusion of shed blood was performed, when necessary to maintain MAP stable during the shock phase. At the end of the shock phase the animals were randomly assigned in two groups, according to the solution to be infused:

1. $R L(n=8)$ : received Ringer Lactated (four times shed blood volume) within $20 \mathrm{~min}$.

2. HSS $(n=8)$ : received $\mathrm{NaCl} 7,5 \%$ (10\% shed blood volume) within $2 \mathrm{~min}$.

After the initial resuscitation phase (20 min) the animals received $40 \mathrm{ml} / \mathrm{Kg} / \mathrm{h}$ normal saline during more $20 \mathrm{~min}$, whereas the wounds were closed. An additional group of three animals served as controls. They were subjected to the surgical procedure but without shock and resuscitation. Blood samples were taken similarly and bile flow collected and recorded.

\section{Sampling and assays}

Alanine aminotransferase (ALT) and total bilirubins

The plasmatic ALT and total bilirubins assays were made with standard kits (LABTEST ${ }^{\circledR}$ - Diagnostic, Belo Horizonte, Minas Gerais, Brazil).

\section{Statistical analysis}

Data are expressed as means \pm standard error of mean ( \pm SEM). The results were tested using the Sigma Stat 3.0 and graphics made with Sigma Plot 8.0. Between the treatment groups data were compared using the MannWhitney U-test. Multiple comparisons among the control and treatment groups were tested at each time point by Kruskal-Wallis analysis of variance on ranks followed by a Dunn's test. Comparison within the groups to test for time effects was performed by means of ANOVA for repeated measures on ranks, followed by Tukey test, or Wilcoxon signed rank test, when appropriated. The level of significance was assigned to $\mathrm{p}<0,05$.

\section{Results}

\section{Mean arterial pressure}

There was no difference in the MAP between the groups during the experiments. Initial MAP values were around $110 \mathrm{mmHg}$, and after $6 \mathrm{~h}$ of $\mathrm{HS}$ and resuscitation the MAP averaged values near $70 \mathrm{mmHg}$.

\section{Bile flow}

Mean bile flow was $0,34 \pm 0,02 \mathrm{ml} / \mathrm{g}$ liver $/ \mathrm{min}$ in the $\mathrm{RL}$ group, $0,48 \pm 0,03 \mathrm{ml} / \mathrm{g}$ liver / $\mathrm{min}$ in the HSS group and 0,64 $\pm 0,04 \mathrm{ml} / \mathrm{g}$ liver $/ \mathrm{min}$ in the control group. Bile flow was significantly higher in the HSS group in comparison to the RL group $(p<0,05)$, but without difference to the control group (Figure 1).

\section{ALT and total bilirubins}

In the RL group serum ALT ranged from 37,1 $\pm 2,2 \mathrm{U} / \mathrm{l}$ (T0) to $169,6 \pm 3,9 \mathrm{U} / \mathrm{l}(\mathrm{T} 6)(\mathrm{p}<0,001)$. In the HSS group, ALT varied from 39,1 $\pm 2,2 \mathrm{U} / \mathrm{l}$ (T0) to 99,4 $\pm 2,2 \mathrm{U} / \mathrm{l}$ (T6). ALT activity was significantly lower after HSS treatment $(\mathrm{p}<0,001)$ (Figure 2). Serum total bilirubins in the RL group ranged from 0,23 $\pm 0,01 \mathrm{mg} / \mathrm{dl}$ (T0) to 1,68 $\pm 0,05 \mathrm{mg} / \mathrm{dl}$ (T6) $(\mathrm{p}<0,001)$. In the HSS group the values were $0,22 \pm 0,01 \mathrm{mg} / \mathrm{dl}$ (T0) and 
$0,62 \pm 0,03 \mathrm{mg} / \mathrm{dl}(\mathrm{T} 6)(\mathrm{p}<0,001)$. After 6 h of resuscitation, the total bilirubins were significantly lower in the HSS group $(\mathrm{p}<0,001)$ (Figure 3).

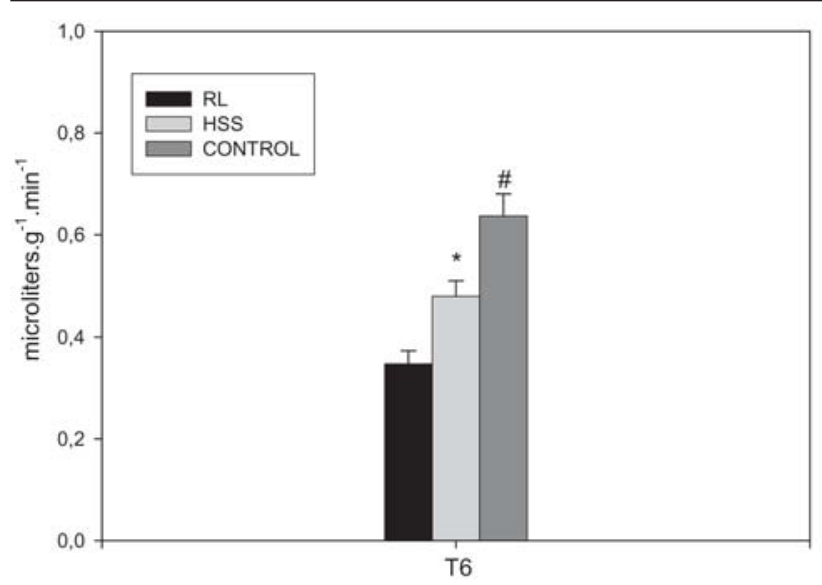

FIGURE 1 - Bile flow in RL $(n=8)$, HSS $(n=8)$ and control $(\mathrm{n}=3)$ groups. ${ }^{*} \mathrm{p}<0.05$ vs LR. $\# \mathrm{p}<0.001$ vs LR. Kruskal-Wallis analysis of variance followed by Dunn's test. Data are means \pm SEM.

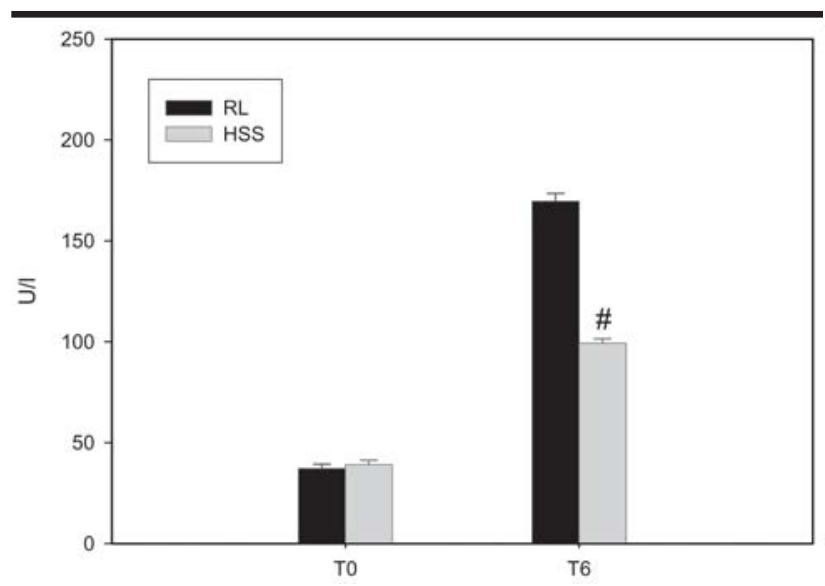

FIGURE 2 - Serum ALT levels at baseline (T0) and after $6 \mathrm{~h}$ treatment (T6) in groups RL $(\mathrm{n}=8)$ and HSS $(\mathrm{n}=8)$. \# $\mathrm{p}<0,001$ vs RL. Mann-Whitney U test. Data are means \pm SEM.

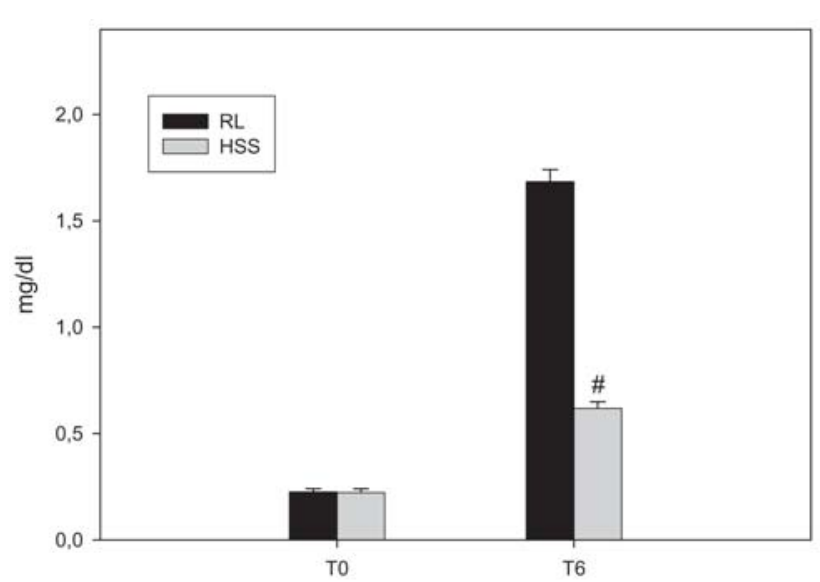

FIGURE 3 - Serum total bilirubin levels at baseline (T0) and after 6 h of resuscitation (T6) in LR ( $\mathrm{n}=8)$ and HSS ( $n=8)$ groups. \# $\mathrm{p}<0,001$ vs LR. MannWhitney $U$ test. Data are means \pm SEM.

\section{Discussion}

Hemorrhagic shock and the consequences of its treatment (ischemia and reperfusion) are considered etiologic factors to acute hepatic liver failure. This can be noticed by the significant bile flow decrease and significant increase of the transaminases activity and plasmatic bilirubins ${ }^{6,14,15}$. It has been demonstrated that long periods of hepatic hypoperfusion promote structural deterioration, metabolic dysfunction and microcirculatory disorders, which are early detectable after 2 hours of ischemia. Until this moment, these phenomena are reversible. Therefore, the time to start the fluid reposition and the duration of reperfusion are determinant to the injury generation ${ }^{15}$. Changes in the bile flow after shock and resuscitation are directly related to the hepatocytes blood supply and are consequence of the dysfunction of $\mathrm{Na}^{+} / \mathrm{K}^{+}$ATPase pump ${ }^{12}$. Thus, severe shock can decrease or even stop the bile flow, with only a partial recovery after resuscitation to levels around $70 \%$ of the baseline ${ }^{6,15}$. When the groups were compared after 6 hours of resuscitation, we verified a significant reduction of bile flow in the RL group compared to the controls, and it was also significantly smaller than the HSS group. The RL bile flow was only $53 \%$ of the control group, whereas the HSS bile flow corresponded to $75 \%$ of the controls, showing recovery to baseline levels. These findings are solid evidences about the superiority of the HSS therapy in the recovery of the hepatic microcirculatory blood supply and decreasing of the anaerobic cycle of the hepatocytes, while the RL treatment was not able to revert the metabolic depression of the shock state after 6 hours of the reperfusion in the same extension. The ALT is released from the hepatocytes according to the severity of cell damage and is, therefore, an useful marker of liver dysfunction ${ }^{16}$. In line with Jarrar et al ${ }^{16}$, our results showed a significant increase of the plasmatic ALT activity in both treatment groups after shock and resuscitation. However, after 6 hours of resuscitation this increase was significantly attenuated in the HSS group. Some authors have demonstrated that $\mathrm{RL}$ resuscitation (3 times the shed blood) restore the hepatocellular function immediately after resuscitation ${ }^{17-19}$. However, ours results have demonstrated that after 6 hours of the resuscitation the hepatocellular function remains compromised, showing clearly a significant reduction in the bile flow. In this experimental model of HS and resuscitation we showed an improvement of the hepatic function in the HSS group, demonstrated by bile flow recovery to baseline levels, and also a maintenance of the hepatic cells integrity, determined by decreased values of plasmatic bilirubins and ALT. The bile flow recovery, the small increase of plasmatic bilirubins and ALT levels in the HSS group strongly suggest a clear improvement of the hepatic nutrition, a better cellular perfusion and less hepatocellular injury. Our results demonstrate the HSS superiority when compared to RL related to hepatic function and integrity after 6 hours of resuscitation of HS in rats.

\section{Conclusion}

Resuscitation of HS with $\mathrm{NaCl} 7.5 \%$ promoted better recovery of liver function and lesser hepatocellular damage 
after $6 \mathrm{~h}$ of treatment compared to RL. The improvement is very likely related to increased microvascular perfusion provided by small volume resuscitation.

\section{References}

1. American College of Surgeons. Committee on Trauma. ATLS - Advanced Trauma Life Support for Doctors Instructor Course Manual. 6ed. Chicago, IL; 1997

2. Paxian M, Rensing H, Geckeis K, Bauer I, Kubulus D, Spahn DR et al. Perflubron emulsion in prolonged hemorrhagic shock: influence on hepatocellular energy metabolism and oxygen-dependent gene expression. Anesthesiology. 2003; 98(6):1391-9.

3. Rizoli SB. Crystalloids and colloids in trauma resuscitation: a brief overview of the current debate. J Trauma. 2003; 54(5 Suppl):S82-8.

4. Gurfinkel V, Poggetti RS, Fontes B, Ferreira Novo FC, Birolini D. Hypertonic saline improves tissue oxygenation and reduces systemic and pulmonary inflammatory response caused by hemorrhagic shock. J Trauma. 2003; 54(6):1137-45.

5. Gushchin V, Stegalkina S, Alam HB, Kirkpatrick JR, Rhee $\mathrm{PM}$, Koustova E. Cytokine expression profiling in human leukocytes after exposure to hypertonic and isotonic fluids. J Trauma. 2002; 52(5):867-71.

6. Corso CO, Okamoto S, Ruttinger D, Messmer K. Hypertonic saline dextran attenuates leukocyte accumulation in the liver after hemorrhagic shock and resuscitation. J Trauma. 1999; 46(3):417-23.

7. Vassar MJ, Fischer RP, O’Brien PE, Bachulis BL, Chambers JA, Hoyt DB et al. A multicenter trial for resuscitation of injured patients with $7.5 \%$ sodium chloride: the effect of added dextran 70 . The Multicenter group for the study of hypertonic saline in trauma patients. Arch Surg. 1993; 128(9):1003-11.

8. Kreimeier U, Messmer K. Small-volume resuscitation: from experimental evidence to clinical routine. Advantages and disadvantages of hypertonic solutions. Acta Anaesthesiol Scand. 2002; 46(6):625-38.

9. Wade CE, Hannon JP, Bossone CA, Hunt MM, Loveday JA, Coppes R et al. Resuscitation of conscious pigs following hemorrhage: comparative efficacy of smallvolume resuscitation. Circ Shock. 1989; 29(3):193-04.

10. Shi HP, Deitch EA, Da Xu Z, Lu Q, Hauser CJ. Hypertonic saline improves intestinal mucosa barrier function and lung injury after trauma-hemorrhagic shock. Shock. 2002; 17(6):496-01.

11. Traverso LW, Bellamy RF, Hollenbach SJ, Witcher LD. Hypertonic sodium chloride solutions: effect on hemodynamics and survival after hemorrhage in swine. J Trauma. 1987; 27(1):32-9.

12. Corso CO, Okamoto S, Leiderer R, Messmer K. Resuscitation with hypertonic saline dextran reduces endothelial cell swelling and improves hepatic microvascular perfusion and function after hemorrhagic shock. J Surg Res. 1998; 80(2):210-20.

13. Vollmar B, Lang G, Menger MD, Messmer K. Hypertonic hydroxyethyl starch restores hepatic microvascular perfusion in hemorrhagic shock. Am J Physiol. 1994; 266(5 Pt 2):H1927-34.

14. Xu QX, Ding YT, Qiu YD, Yu DC, Zhang HY. A reliable graded acute liver failure model in rats: treatment with internal bioartificial liver. Hepatobiliary Pancreat Dis Int. 2004; 3(2):254-8.

15. Adkison D, Hollwarth ME, Benoit JN, Parks DA, McCord JM, Granger DN. Role of free radicals in ischemiareperfusion injury to the liver. Acta Physiol Scand. 1986; 548:101-7.

16. Jarrar D, Wang P, Cioffi WG, Bland KI, Chaudry IH. Critical role of oxygen radicals in the initiation of hepatic depression after trauma hemorrhage. J Trauma. 2000; 49(5):879-85.

17. Deb S, Martin B, Sun L, Ruff P, Burris D, Rich N et al. Resuscitation with lactated Ringer's solution in rats with hemorrhagic shock induces immediate apoptosis. J Trauma. 1999; 46(4):582-8.

18. Shah KJ, Chiu WC, Scalea TM, Carlson DE. Detrimental effects of rapid fluid resuscitation on hepatocellular function and survival after hemorrhagic shock. Shock. 2002; 18(3):242-7.

19. Wang P, Chaudry IH. Crystalloid resuscitation restores but does not maintain cardiac output following severe hemorrhage. J Surg Res. 1991; 50(2):163-9.

\section{Correspondence:}

Ricardo Antonio Hoppen

Rua Fagundes dos Reis, 466/303

99070-030 Passo Fundo-RS Brazil

Phone: (55 54)311-1883

Fax:(5554)313-8383

rhoppen@annex.com.br
Conflict of interest: none Financial source: none

Received: May 20, 2005

Review: June 15, 2005

Accepted: July 19, 2005

\section{How to cite this article:}

Hoppen RA, Corso CO, GrezzanaJM, Severino A, Dal-Pizzol F, Ritter C. Hypertonic saline and hemorrhagic shock: hepatocellular function and integrity after six hours of treatment. Acta Cir Bras. [serial on the Internet] 2005 Nov-Dec;20(6). Available from URL: http://wwwscielo.br/acb 